\title{
Civil Banishment of Gang Members: Circumventing Criminal Due Process Requirements?
}

\author{
Stephanie Smith $\dagger$
}

Gang-related violence is a serious problem facing communities across the United States. Gangs have taken over neighborhoods and have left innocent citizens terrified to enter public spaces. ${ }^{1}$ Part of what makes the gang problem in America so staggering is that conventional crime-fighting techniques have proven particularly ineffective at reducing gang activity. ${ }^{2}$ Faced with growing gang problems and an inability to stop gangs through conventional techniques, communities have begun to turn to the civil justice system as an alternative.

For example, Cicero, Illinois, recently passed a gang free zones ordinance allowing the town to exile gang members through civil banishment. The ordinance is believed to be the first of its kind in the nation $^{4}$ and creates a unique civil remedy against gang violence that could serve as a model for other communities." Under the ordinance, following a civil administrative hearing, gang members found by a preponderance of the evidence to have engaged in gang-related criminal activity are ordered to leave Cicero and face severe fines if they return.

While gang violence is a serious problem, there are limits to the measures communities can take to combat gangs. Gang members' constitutional rights constrain the range of alternatives available, as evidenced by a recent Supreme Court decision striking down a Chicago gang loitering ordinance even though the city claimed its enforcement reduced gang-related crime.' Therefore, it is important to examine the constitutionality of civil responses like the Cicero ordinance before it is enforced or other cities decide to enact similar

$\dagger$ B.S. 1996, Rice University; J.D. Candidate 2001, The University of Chicago.

See notes 11-12 and accompanying text.

2 See note 10.

3 An Ordinance Providing for the Enforcement of Gang Free Zones in the Town of Cicero ("Gang Free Zones Ordinance"), Ordinance No 111-99 (Apr 1999), amending Cicero Code of Ordinances ch 25.

4 See Illinois Town Sues Gangs for Damages, AP (May 12,1999) (describing Cicero's gang free zones law as "an extraordinary ordinance ... believed to be the first of its kind in the nation").

5 See note 47 and accompanying text.

6 Gang Free Zones Ordinance $\$ 25-300(\mathrm{a})(\mathrm{F})-(\mathrm{G}), 25-300(\mathrm{c})(\mathrm{A})-(\mathrm{B})$.

7 City of Chicago $v$ Morales, 527 US 41, 48-51 (1999) (holding that Chicago gang loitering ordinance was unconstitutionally vague). 
measures. This Comment provides an analytic framework for evaluating civil responses to the gang problem in America. Civil responses are attractive because they are less expensive and the government faces a lower burden of proof; however, when the civil justice system is used to administer serious penalties, the constitutional concerns outlined in this Comment should be considered.

This Comment argues that civil banishment is unconstitutional because it actually administers a criminal penalty through a civil hearing and therefore provides inadequate procedural safeguards to gang members. Furthermore, even if civil banishment ordinances, such as the one Cicero has enacted to combat gangs, were reclassified as criminal and the relevant procedural safeguards that are currently lacking were added, courts would still be unlikely to enforce banishment of gang members because state laws often proscribe or severely limit the use of banishment as a criminal penalty. Therefore, this Comment argues that the Cicero ordinance should not be enforced, and other cities should not adopt civil banishment procedures in the ongoing war against gangs.

Part I of this Comment explores the growing problem of gang violence in America, the ineffectiveness of conventional techniques for combating this violence, and the creative techniques that cities have begun to use to combat it. Part I also focuses on civil banishment remedies, such as the ordinance passed by the town of Cicero. Part II discusses the nature of the distinction between civil and criminal penalties and argues that civil banishment imposes a criminal penalty though a civil hearing in violation of constitutional due process protections. Finally, Part III argues that courts would not enforce a civil or criminal banishment of gang members in light of existing state banishment law.

\section{THE GROWTH OF GANG VIOLENCE IN AMERICA AND LAW ENFORCEMENT RESPONSES}

Gang violence is a staggering problem facing cities across America.' Traditional criminal law enforcement methods have proven inadequate, and communities have had to respond with innovative law

8 See notes 60-61 and accompanying text (proof beyond a reasonable doubt standard limited to criminal context); note 65 and accompanying text (civil law techniques less expensive than criminal procedures).

9 See Gregory S. Walston, Taking the Constitution at Its Word: A Defense of the Use of Anti-Gang Injunctions, 54 U Miami L Rev 47, 47 (1999) (stating that gang violence is no longer confined to inner cities but has "erupted to threaten virtually all neighborhoods in America"); Terence R. Boga, Note, Turf Wars: Street Gangs, Local Governments, and the Battle for Public Space, 29 Harv CR-CL L Rev 477, 477 (1994) (stating that "gang violence has escalated to the point of ubiquity, resulting in the mutilation and death of countless participants and innocent bystanders"). 
enforcement techniques. ${ }^{10}$ This Part briefly describes the overwhelming problem of gang violence in America and the creative responses of communities to mounting urban chaos. This Part then focuses on civil banishment remedies, such as the innovative gang free zones ordinance passed by the town of Cicero, Illinois.

\section{A. Gang Violence in America}

Gang violence is a pervasive problem ravaging cities around the country and leaving innocent citizens afraid to enter public spaces." Recently Justice Thomas stated that in many cities, "gangs have virtually overtaken certain neighborhoods ... causing fear and lifestyle changes among law-abiding residents." ${ }^{\text {,12 }}$ Gangs reportedly exist in 94 percent of major cities and are present in at least 1,130 cities of all sizes in America. ${ }^{13}$ One estimate reports that there are over sixteen thousand gangs in the nation, over five hundred thousand gang members, and nearly six hundred thousand annual gang-related crimes. ${ }^{14}$ In Chicago alone, for example, it has been estimated that there were 132 criminal street gangs in 1996 and that between 1987 and 1994 these gangs were "involved in 63,141 criminal incidents.",

Part of what makes the gang problem so staggering is that conventional crime-fighting techniques have been ineffective at stopping gang activity. ${ }^{16}$ Gang members establish control over areas of cities and avoid arrest by only committing criminal offenses when they know officers are not in the vicinity. "While most people who intend

10 See Walston, $54 \mathrm{U}$ Miami L Rev at 48 (cited in note 9) ("The rising problem of gang violence has overwhelmed conventional law enforcement techniques."); Matthew Mickle Werdegar, Note, Enjoining the Constitution: The Use of Public Nuisance Abatement Injunctions Against Urban Street Gangs, 51 Stan L Rev 409, 410 \& n 6 (1999) (noting that gang-related crime has "proven highly resistant to traditional crime fighting methods" and citing numerous reports of the failure of traditional law enforcement methods to effectively stop gangs); Boga, Note, 29 Harv CR-CL L Rev at 477 (cited in note 9) (noting that "there is growing sentiment that new law enforcement techniques are necessary to stymie [ ] mounting urban disorder").

11 See Gary Stewart, Note, Black Codes and Broken Windows: The Legacy of Racial Hegemony in Anti-Gang Civil Injunctions, 107 Yale L J 2249, 2249 (1998) (stating that gang members are holding innocent people "hostage[ ] in the 'hood' leaving [them] afraid for their lives in public spaces").

12 City of Chicago v Morales, 527 US 41, 99-100 (1999) (Thomas dissenting) (also stating that citizens are often relegated to the status of prisoners in their own homes) (internal quotation marks omitted).

13 See Marilyn Tower Oliver, Gangs: Trouble in the Streets 7 (Enslow 1995).

14 See G. David Curry, Richard A. Ball, and Scott H. Decker, Estimating the National Scope of Gang Crime from Law Enforcement Data, in C. Ronald Huff, ed, Gangs in America 21, 31 (Sage 2d ed 1996) (providing table with estimated numbers of gangs, members, and gang crimes in cities of different sizes, for selected counties, and for the nation as a whole).

15 Morales, 527 US at 99 (Thomas dissenting) (discussing Chicago gang violence statistics).

16 See note 10.

17 Morales, 527 US at 45-47 (describing Chicago city council findings that led to the enactment of the invalidated Gang Congregation Ordinance prohibiting criminal street gang mem- 
to commit crimes will not do so if an officer is present, the prevalence of gang crime coupled with gang members' ability to avoid being caught makes fighting gangs with the traditional criminal justice system difficult. Furthermore, gang members often intimidate potential witnesses into refusing to testify or to report crimes in the first place. ${ }^{18}$ While under-reporting is problematic in other areas of criminal law as well, it seems particularly prevalent in the gang context given people's fear of gangs." Traditional methods of enforcement are still important, but communities and prosecutors have found that they need "more tools" in the fight against gangs because conventional criminal sanctions have not reduced gang activity sufficiently.

\section{B. Community Responses}

Faced with the inability to stop gang crime through conventional techniques, communities have begun to turn to the civil justice system as an alternative because of its more lenient standards of proof and lower litigation costs. ${ }^{21}$ The most common innovative measure, first championed in California, is an anti-gang civil injunction issued pursuant to courts' nuisance abatement powers. ${ }^{2}$ Under this approach, cities identify gang turfs, gang members, and unlawful or antisocial gang activity. ${ }^{23}$ The cities then file civil suits requesting that the court declare the gang to be a public nuisance and enjoin the named defendants, "numbering from a dozen to over three hundred," from engaging in a variety of activities. While the injunctions are tailored to individual cases, many share common provisions such as prohibiting gang members from committing illegal acts, from associating in public with other gang members, and from harassing innocent third parties.

bers from loitering).

18 Walston, $54 \mathrm{U}$ Miami L Rev at 48 (cited in note 9) (describing reasons that gang violence has "overwhelmed conventional law enforcement techniques").

19 See notes 11-12 and accompanying text.

20 Art Barnum, County Files Anti-Gang Suit: Unused State Law Cited in Civil Case Against Twenty Two West Chicago Defendants, Chi Trib 1 (Oct 5, 1999) (quoting State Attorney's justification for seeking a civil injunction against gang leaders in Cicero, Illinois barring their gang activities).

21 See notes 61 and 65 and accompanying text.

22 See, for example, Walston, 54 U Miami L Rev at 48 (cited in note 9) (stating that in the search for improved gang prevention, the most effective new technique is "enjoining the gang as a public nuisance"); Werdegar, Note, 51 Stan L Rev at 411 (cited in note 10) (noting that California has "pioneered the use of public nuisance law to obtain sweeping civil injunctions" against gang members); Stewart, Note, 107 Yale L J at 2249 (cited in note 11) (stating that many state and local governments "have adopted new criminal and civil approaches designed to abate the 'nuisance' of gang existence").

23 Werdegar, Note, 51 Stan L Rev at 416-17 (cited in note 10) (discussing processes cities use to obtain nuisance abatement injunctions against gangs).

24 Id.

25 Id at 417 (discussing typical provisions under nuisance abatement injunctions). 
These measures have been criticized as effectively banishing street gang members from public spaces ${ }^{26}$ without sufficient proof of specific crimes and harming minority communities. ${ }^{27}$ Additionally, the injunctions have been denounced as unconstitutionally vague ${ }^{2 x}$ and violative of gang members' right to due process of law. However, a divided California Supreme Court upheld the constitutionality of using injunctions to abate the public nuisance of gangs. ${ }^{30}$ Some commentators have praised the measures, ${ }^{31}$ and communities that have used the injunctions have "declared them to be unqualified successes." The use of anti-gang injunctions has spread throughout the country, showing the desire of communities to use the civil justice system to bolster their efforts to reduce gang activity.

\section{Civil Banishment and the Cicero Gang Free Zones Ordinance}

In their search for innovative ways to combat gang crime, some towns have not stopped at the filing of public nuisance suits. For example, the town of Cicero, Illinois has adopted another, more aggressive technique in its battle against street gangs: civil banishment of gang members. ${ }^{33}$ Cicero has been faced with growing gang problems in recent years. ${ }^{34}$ Last April, the town passed a controversial ordinance

26 See Boga, Note, 29 Harv CR-CL L Rev at 492 (cited in note 9) (stating that municipalities are "on the verge of decreeing that [street gang members] are not suitable for any public space at any time").

27 See Stewart, Note, 107 Yale L J at 2250-51 (cited in note 11) (criticizing anti-gang civil injunctions as harming minority communities and perpetuating "racial stigma and oppression").

28 See Werdegar, Note, 51 Stan L Rev at 427-28 (cited in note 10) (discussing problems of arbitrary and discriminatory enforcement allowed under anti-gang injunctions). See also Gallo $v$ Acuna, 929 P2d 596, 629-30 (Cal 1997) (Mosk dissenting) (concluding anti-gang injunction violated vagueness and overbreadth doctrines).

29 See Werdegar, Note, 51 Stan L Rev at 433-34 (cited in note 10) (discussing the constitutional due process issues raised by the lack of procedural safeguards in civil anti-gang injunction cases); Stewart, Note, 107 Yale L J at 2266-67 (cited in note 11) (noting that civil hearings entitle defendants to "much less stringent and comprehensive" due process guarantees).

30 Acuna, $929 \mathrm{P} 2 \mathrm{~d}$ at 608-14 (holding that the nuisance abatement injunction issued against gang members did not violate their First Amendment rights of free speech or association and was not impermissibly overbroad or vague).

31 Walston, 54 U Miami L Rev at 53 (cited in note 9) (stating that "[b]ecause it is unreasonable to expect the common citizen to constantly be subjected to the inherent intimidation and violence of criminal street gangs, anti-gang injunctions present the proper solution for resolving the conflict between the interests of public safety and the civil liberties of gang members").

32 Werdegar, Note, 51 Stan L Rev at 411 (cited in note 10) (discussing the evident approval of anti-gang injunctions by law enforcement, politicians, and the courts).

33 See Eric Slater, Suburb Gives Gang Members 60 Days to Leave, Austin AmericanStatesman A12 (May 2,1999) (stating that measures taken by Cicero are "stricter than any now on the books").

34 See Robert Becker and Rob D. Kaiser, Cicero Taking Its Gang Fight to Court: Suits Seek Millions and Judicial Orders to Restrict Activities, Chi Trib 1 (May 12,1999) (reporting that police have identified eighteen gangs in Cicero); Pam Belluck, Capone's Old Haven in Illinois Wants to 
making the town a gang free zone. ${ }^{35}$ Under the ordinance, the Superintendent of Police can request that the Town Attorney bring a civil action against a street gang member to banish the accused from Cicero. The complaint must allege evidence that the street gang member "engaged in gang-related criminal activity in the community which presents a clear and present danger to the public order and safety." hearing on the complaint is conducted in front of an administrative hearing officer designated by the Town Board, not a criminal court judge. ${ }^{38}$ The ordinance does not indicate how the hearing officer is selected or what position the hearing officer holds in the town. "If the hearing officer finds that the accused is a gang member and has engaged in gang-related criminal activity," the accused is effectively banished from the town by an order to "vacate his residence." to vacate is to be enforced by the Superintendent of Police, and if the gang member stays within Cicero or subsequently reenters Cicero, he is fined $\$ 500$ for each day he is present in the town. Although a oneyear probationary period may be granted if the accused renounces all gang activity, ${ }^{41}$ the banishment from Cicero lasts indefinitely under the ordinance, and there is no provision allowing the accused to seek permission to visit the town for any reason.

In the hearing under the ordinance, the rules of evidence do not apply. For example, "hearsay shall be admissible" to determine if the accused has been involved in gang-related activity. More importantly, during this civil proceeding, the town only has to prove involvement in gang-related activity by a preponderance of the evidence, ${ }^{43}$ lower than the "beyond a reasonable doubt" standard required in criminal cases."

Evict Gang Members, Deseret News A6 (May 9, 1999) (stating that Cicero officials reported sixty-four shootings and fifteen homicides in 1998 and twenty-four shootings and two homicides in the first four months of 1999, almost all gang related). In comparison, approximately onequarter, or 175, of Chicago's 700 homicides in 1998 were gang related. See Steve Mills, One Step to Reform, Two Steps Back: Corruption, Brutality Charges Still Tarnish Police, Chi Trib 1 (Feb 11, 1999).

35 See Tammy Webber, Illinois Suburb OKs Anti-Gang Ordinance, AP (Apr 28, 1999) (reporting that the Cicero ordinance making the town a gang free zone was passed by 95 percent of the voters and unanimously enacted by the Town Board).

36 Gang Free Zones Ordinance \& 25-300(a)(C).

37 Id.

38 Id $\$ 25-300(a)(E)$. However, a gang member can file an appeal from an order to leave Cicero with the Circuit Court of Cook County. See id $\$ 25-300(a)(J)$.

39 Id $\S 25-300(a)(G)$.

40 Id $\S 25-300(a)(G), 25-300(c)(A)-(B)$.

41 Id $\S 25-300(\mathrm{a})(\mathrm{H})$. See also $\$ 25-300(\mathrm{a})(\mathrm{I})$ (for individuals sixteen and younger the ordinance allows for a probationary period if the parents of the accused agree that the accused will cease gang activity).

42 Id $\$ 25-300(a)(E)$.

43 Id \$25-300(a)(F).

44 See note 61 and accompanying text. 
However, the accused does have a "right to discovery and to be represented by an attorney" at the hearing."

Even though Cicero has not enforced the ordinance to date, the ordinance has nonetheless had effects on the community. In the wake of its passage and the surrounding publicity, it has been reported that people have left Cicero to avoid potential enforcement actions. ${ }^{45}$ Furthermore, other cities have considered adopting similar measures and Cicero hopes to be a model to other communities throughout the nation."

When Cicero passed the ordinance, many thought it was an extreme, and likely unconstitutional, measure. ${ }^{48}$ Some commentators thought that the ordinance was unconstitutionally vague, ${ }^{49}$ while others thought it impermissible because it punishes someone for his

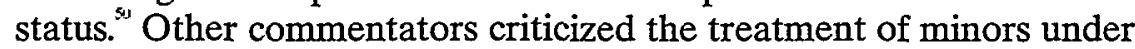
the ordinance ${ }^{51}$ and expressed reservations about pushing gang members into surrounding communities. ${ }^{32}$ Still others expressed concern that the ordinance would work along racial lines..$^{53}$ However, none of

45 Gang Free Zones Ordinance \$25-300(a)(E).

46 See Rob D. Kaiser, Suits Targeting Gangs Have Town Split in Two, Chi Trib 1 (metro section) (May 13, 1999) (relaying anecdotal evidence that six or seven people have left Cicero already out of fear of banishment); Slater, Suburb Gives Gang Members 60 Days to Leave, Austin American-Statesman at A12 (cited in note 33) (reporting that Cicero town president Betty Loren-Maltese thinks a lot of families will "see the handwriting on the wall and will leave").

47 See John Flink, Alderman Urges Cicero-style Law to Battle Gangs, Chi Trib 3 (metro section) (May 19, 1999) (reporting Waukegan alderman suggesting that town look into prohibiting gangs); Betty Loren-Maltese, Ridding Cicero of Gangs, Chi Trib 14 (May 4, 1999) (quoting Cicero town president stating that Cicero's ordinance will serve as a model for other communities and that the town had already received over thirty requests from other municipalities for copies of the ordinance).

48 John Kass, Cicero Keeping Streets, Alleys Safe from Little Hoopsters, Chi Trib 3 (May 18, 1999) (stating that, because of the ordinance, constitutional scholars think Cicero's town president is "wacky").

49 See, for example, Stephen E. Sachs, When Only "Good People" Have Rights, St. Louis Post-Dispatch B15 (Aug 10, 1999) (stating that the Cicero ordinance is likely to be unconstitutional because its" expansive definition of street gang "opens up the door for arbitrary and discriminatory enforcement" and quoting Northwestern University law professor Dan Polsby as saying that "[s]ome ordinances are unconstitutional, but this one is unconstitutional as hell").

50 Town's Anti-Gang Laws Raise Eyebrows: Legal Experts Believe Attempts to Kick Out All Gangsters are Unconstitutional, Salt Lake Trib D1 (Apr 29,1999) (quoting the executive director of the ACLU as stating that the ordinance is unconstitutional "because [it] charge[s] somebody for their status[,] ... not a crime").

51 See, for example, Editorial, Gang Busting, Daily Athenaeum (Apr 29, 1999) (noting that when gang members under age eighteen are forced to leave under the ordinance, their parents have to "move out with them or send them to live with out-of-town relatives").

52 See, for example, Brian Knowlton, Cicero, Illinois to Gangs: Get Out of Town, Intl Herald Trib 3 (Apr 30, 1999) (expressing concern that the ordinance allows Cicero to "foist" its problems on other towns).

53 See, for example, Illinois Town Sues Gangs for Damages, AP (cited in note 4) (quoting University of Chicago Professor Stephen Schulhofer as saying that "[w] hat you worry about is when something like this gives (the town) the power to sweep every Latin kid off the street"); 
these reports focused on the fact that the ordinance is imposing a criminal penalty through a civil hearing. Other cities that model the Cicero ordinance could likely draft their ordinances so as to avoid many of the constitutional challenges, such as vagueness. However, the criminal-civil distinction problem implicates the two most important features of Cicero's ordinance that other communities could not simply draft around: the civil nature of the proceeding and the punishment of banishment. This Comment argues that civil banishment exceeds the limit on the extent to which the civil system can be used to supplant the criminal system in combating gangs, because banishment is an extremely severe punishment. Furthermore, this Comment argues in Part III that banishment of gang members from an entire city would likely be struck down under existing state law even if criminal procedural protections were provided. Therefore, other cities modeling Cicero's ordinance could not draft around the two central features of Cicero's ordinance to save their measures from invalidity.

\section{Civil Banishment Imposes a CRIMINAL Penalty through A CIVIL HEARING}

For years the law has distinguished between criminal and civil proceedings." This Part details the tests that courts and commentators have used to determine if an action is criminal or civil and explores recent Supreme Court applications of these tests. Although the distinction between civil and criminal actions has been rapidly collapsing in recent years, ${ }^{5 s}$ this Part argues that it is still important to draw the distinction in many cases, especially where a serious loss of liberty such as banishment is at stake. This Part then argues that civil banishment is a criminal penalty couched as a civil one, and that a court should not allow this deprivation of constitutional procedural protections guaranteed in criminal proceedings.

\section{A. The Criminal-Civil Distinction}

The division between criminal and civil law is deeply ingrained in English and American law, and the Supreme Court continues to take

\footnotetext{
Slater, Suburb Gives Gang Members 60 Days to Leave, Austin American-Statesman at A12 (cited in note 33) (reporting that opponents of the ordinance are concerned that it will "work along racial lines" against the influx of Latinos into predominantly white Cicero). But see Editorial, Try Again on Gangs, Chi Sun-Times 31 (June 14,1999) (stating that among those targeted by the ordinance are members of a Caucasian gang, the Nobel Knights).

54 See, for example, Susan R. Klein, Redrawing the Criminal-Civil Boundary, 2 Buff Crim L Rev 679,679 (1999) (stating that "[o]ne of the most profound boundaries our justice system has drawn is that between the terrain of civil and criminal law").

55 See notes 63-64 and accompanying text.

56 See Kenneth Mann, Punitive Civil Sanctions: The Middleground Between Criminal and
} 
the distinction seriously. ${ }^{\text {.7 }}$ The distinction is important because many constitutional procedural safeguards are only available in criminal proceedings. For example, the Self-Incrimination Clause in the Fifth Amendment is expressly limited to "any criminal case," and the Sixth Amendment protections of the rights to a speedy trial, trial by jury, confrontation of witnesses, compulsory process, and assistance of counsel are only available to the accused in "criminal prosecutions." Furthermore, other constitutional protections, such as the Double Jeopardy Clause protection against repeat punishment for the same offense and the requirement of proof beyond a reasonable doubt, have been limited to the criminal context by the Supreme Court. ${ }^{50}$ Therefore, properly classifying a proceeding as criminal or civil is extremely important to determine the constitutional rights of defendants.

The paradigmatic distinction between the two types of proceedings is that the criminal law is punitive while the civil law is compensatory. ${ }^{62}$ However, this paradigm of the criminal-civil distinction has been rapidly collapsing ${ }^{33}$ in large part due to the recognition that the civil system can be used, not only to compensate, but also to deter undesirable behavior in the same way that the criminal system deters. ${ }^{A}$ Many

Civil Law, 101 Yale L J 1795, 1803 (1992) (discussing historic division between criminal and civil law dating back to the fourteenth and fifteenth centuries).

57 See, for example, Stephen J. Schulhofer, Two Systems of Social Protection: Comments on the Civil-Criminal Distinction, with Particular Reference to Sexually Violent Predator Laws, $7 \mathrm{~J}$ Contemp Legal Issues 69, 78 (1996) (stating that the Court takes the distinction seriously and that there are "good grounds for its durability").

58 US Const Amend V.

59 US Const Amend VI.

60 See United States $v$ Ward, 448 US 242, 248 (1980) (stating that these protections "while not explicitly limited to one context or the other, have been so limited" by the Court to the criminal context).

61 See, for example, John C. Coffee, Paradigms Lost:The Blurring of the Criminal and Civil Law Models-And What Can Be Done about It, 101 Yale L J 1875, 1888 (1992) (stating that civil penalties "could provide the means for evading constitutional safeguards" guaranteed in the criminal context).

62 See, for example, Mann, 101 Yale L J at 1799, 1807-09 (cited in note 56) (discussing the respective paradigmatic purposes of criminal and civil law); Coffee, 101 Yale L J at 1884 (cited in note 61) (stating that "the criminal law prohibits, while the civil law prices"); Mary M. Cheh, Constitutional Limits on Using Civil Remedies to Achieve Criminal Law Objectives: Understanding and Transcending the Criminal-Civil Law Distinction, 42 Hastings L J 1325, 1354-55 (1991) (noting that commentators state that "recompense of the injured ... is the hallmark of a civil proceeding" while criminal punishment is traditionally for seeking retribution).

63 See, for example, Carol S. Steiker, Punishment and Procedure: Punishment Theory and the Criminal-Civil Procedural Divide, 85 Georgetown L J 775, 783-84 (1997) (discussing the increasing "blurring or destabilization" of the criminal-civil distinction); Coffee, 101 Yale L J at 1875 (cited in note 61) (stating that the "line between civil and criminal penalties is rapidly collapsing"); Cheh, 42 Hastings L J at 1327 (cited in note 62) (stating that the "current phenomenon of civil remedies blending with criminal sanctions never has been more actively or consciously pursued").

64 See United States v Ursery, 518 US 267, 292 (1996) (noting that deterrence "may serve 
legislative bodies are now turning to civil law techniques to stop antisocial behavior because they are less expensive and unencumbered by the rigorous constitutional protections associated with criminal trials. However, given the lack of many procedural safeguards in a civil pro- ceeding, it is still important to ensure that criminal sanctions are not being administered through a civil proceeding in violation of a defendant's constitutional rights. It is helpful when making the criminal-civil a distinction to recognize that core criminal remedies are incarceration and the stigma associated with criminal conviction, while the core civil remedies are injunctions or monetary damages to compensate for injuries. ${ }^{66}$ There are heightened procedural protections in the criminal justice system because criminal penalties typically deprive defendants of more than just property, which implicates larger liberty interests. Some commentators have suggested that constitutional criminal procedural protections should be applied to a proceeding, even if it is labeled as civil, if the punishments are as severe as those authorized by criminal laws.

\section{B. Tests for Determining the Nature of a Proceeding}

There is no simple test to use when determining if an action classified as civil is "really" criminal. In United States $v$ Ward, the Su-

civil as well as criminal goals"). See also Mann, 101 Yale $\mathrm{L}$ J at 1845-47 (cited in note 56) (discussing the rise of deterrence theory in law); Steiker, 85 Georgetown L J at 784-87 (cited in note 63) (discussing how the growth of "law and economics" has challenged the distinction between civil and criminal sanctions by recasting them as "related parts of a unitary scheme of state control of private behavior"); Richard A. Posner, Economic Analysis of Law 187, 190 (Little, Brown $3 d$ ed 1986) (arguing that tort remedies and criminal sanctions can both be effective deterrents). See also Steiker, 85 Georgetown L J at 787-97 (cited in note 63) (arguing that changes in cognitive and behavioral sciences and the similarity between modern modes of criminal punishment and civil regulation have also led to the collapse of the criminal-civil distinction in many cases).

65 See, for example, Steiker, 85 Georgetown $\mathrm{L} J$ at 780 (cited in note 63) (stating that the high cost of criminal procedure has led legislators to pursue "civil avenues to address what might more plausibly be classified as criminal conduct"); Cheh, 42 Hastings L J at 1345 (cited in note 62) (noting that the use of civil remedies is growing in part because they are "easier to use, more efficient, and less costly than criminal prosecutions").

66 See Mann, 101 Yale L J at 1809 (cited in note 56) (discussing the paradigmatic differences between criminal and civil remedies). See also Kennedy $v$ Mendoza-Martinez, 372 US 144, 168 (1962) (holding that whether the sanction is an affirmative disability or restraint is a factor in defermining whether it is criminal); Coffee, 101 Yale L J at 1878 (cited in note 61) (noting criminal law's goal of maximizing stigma and censure); Cheh, 42 Hastings $L \mathrm{~J}$ at 1352 (cited in note 62) (noting that commentators have argued that the stigma and social condemnation associated with criminal proceedings distinguish them from civil ones).

67 See Cheh, 42 Hastings $\mathrm{L} J$ at 1350-51 (cited in note 62) (noting the appeal of the "sanction equivalency approach" but also the flaw in the approach because huge punitive damage awards have long been accepted as civil); George Fletcher, Comment, The Concept of Punitive Legislation and the Sixth Amendment: $A$ New Look at Kennedy v. Mendoza-Martinez, 32 U Chi L Rev 290, 292 (1965) (arguing for criminal procedural protections when there are "grave" penalties).

68448 US 242 (1980). 
preme Court outlined a two-part test to determine whether the action should be considered civil or criminal: (1) did the legislative body indicate "either expressly or impliedly a preference for one label or the other"; and (2) despite the civil label, is the "statutory scheme ... so punitive either in purpose or effect as to negate [legislative] intention." Demonstrating a willingness to defer to the legislature, the Court stated that "only the clearest proof" will suffice to override legislative intent under the second part of the test and transform a proceeding denominated as civil into a criminal one. ${ }^{70}$

Under Ward's first prong, a court must ascertain the legislature's preference. Some commentators have dubbed this test the "legislative label approach" because the Court will usually ratify the legislature's decision to classify an action as civil or criminal. ${ }^{71}$ However, even proponents of the legislative label approach admit that there are types of cases that are appropriately classified as criminal regardless of legislative intent. ${ }^{n}$ For example, one commentator has argued that if the punishment in the proceeding is only consistent "with the view that the underlying conduct punished was criminal," then the proceeding should provide criminal constitutional protections. ${ }^{33}$ Therefore, it is important to examine a proceeding to determine if, despite its civil legislative label, it is in fact a criminal proceeding for the purpose of constitutional protections.

In Hudson v United States, ${ }^{74}$ the Court reaffirmed the Ward rule ${ }^{75}$ and stated that the seven-factor test from Kennedy $v$ MendozaMartinez $z^{76}$ serves as a "useful guidepost[ ]" when determining whether, despite the legislative label, a civil remedy is in fact a criminal pen-

69 Id at 248-49 (stating that whether a penalty is civil or criminal "is a matter of statutory construction").

70 Id at 249.

71 See Klein, 2 Buff Crim L Rev at 683 (cited in note 54) (stating that the Supreme Court in the last few terms has routinely "bless[ed] whatever label a legislature places on a sanction"); Cheh, 42 Hastings $L J$ at 1330, 1359-60 (cited in note 62) (advocating legislative label approach because it provides a clear test for making the criminal-civil distinction and because it recognizes that criminal proceedings are public statements of societal boundaries and moral rules and therefore only something the public, through the legislature, has designated as criminal should be treated as such by a court).

72 See Ward, 448 US at 248-49 (noting that there will be cases in which the legislative intention of creating a civil penalty will be negated); Cheh, 42 Hastings L J at 1361-64 (cited in note 62) (noting that there are two types of cases that should be considered criminal regardless of the legislative label).

73 See Cheh, 42 Hastings L J at 1363 (cited in note 62) (stating that if the punishment "so dramatically expresses societal disapproval that its imposition can only be legitimated through the ceremony of a criminal conviction," the legislative label should not be followed in making the criminal-civil distinction). See also Fletcher, Comment, $32 \mathrm{U}$ Chi L Rev at 292 (cited in note 67).

\footnotetext{
$74 \quad 522$ US 93 (1997).

75 Id at 96 (reaffirming the rule established in Ward).

76372 US 144 (1963).
} 
alty. ${ }^{n}$ In Mendoza-Martinez, the Supreme Court developed a sevenfactor comparative test for courts to use to determine whether a civil proceeding is in reality a criminal one requiring attendant constitutional procedural safeguards. ${ }^{78}$ The seven factors are: (1) "[w]hether the sanction involves an affirmative disability or restraint"; (2) "whether it has historically been regarded as a punishment"; (3) "whether it comes into play only on a finding of scienter"; (4) "whether its operation will promote the traditional aims of punishment-retribution and deterrence"; (5) "whether the behavior to which it applies is already a crime"; (6) "whether an alternative purpose to which it may rationally be connected is assignable for it"; and (7) "whether it appears excessive in relation to the alternative purpose assigned." "79

Despite considerable deference to the legislature, the Supreme Court has allowed serious sanctions to be imposed through civil proceedings only when the sanction was limited to the deprivation of property or when the sanction has historically been administered through civil proceedings.

In a series of cases, the Court has demonstrated a willingness to allow punitive forfeitures of property through the civil system. In Bennis $v$ Michigan, ${ }^{80}$ the Court allowed the civil confiscation of an innocent party's property that had been used without her knowledge by someone else in the commission of a crime. ${ }^{81}$ In United States v Ursery, ${ }^{82}$ the Court held that a federal conviction for manufacturing marijuana, following a civil forfeiture action seizing property used to facilitate the same offense, did not violate the Double Jeopardy Clause because civil forfeitures "do not constitute 'punishment' for purposes of the Double Jeopardy Clause." "Finally, in Hudson, the Court held that the Double Jeopardy Clause did not bar a criminal prosecution for

77 522 US at 99-100 (noting usefulness of Mendoza-Martinez factors but also stressing that "'only the clearest proof will suffice to override legislative intent and transform what has been denominated a civil remedy into a criminal penalty") (citations omitted).

78372 US at 167-69 (holding that the loss of citizenship for draft dodging was a criminal punishment that required a "criminal trial and all its incidents" and articulating a seven-factor test to determine if a statute is penal or regulatory in character).

79372 US at $168-69$.

80516 US 442 (1996).

81 Id at 452-53 (holding that civil forfeiture was appropriate because it "serve[d] a deterrent purpose distinct from any punitive purpose" regardless of the party's innocence in the crime committed in her car).

82518 US 267 (1996).

83 Id at 270-71, 287-92 (holding that "in rem civil forfeitures are neither 'punishment' nor criminal for purposes of the Double Jeopardy Clause" because Congress intended the proceedings to be civil and because, given the proceedings' important non-punitive, deterrence goals, there is little proof that the proceedings are "so punitive in form and effect as to render them criminal despite Congress' intent to the contrary"). 
violating banking statutes subsequent to the civil imposition of monetary penalties and debarment for the same conduct.

The Court has also ratified the civil label of a proceeding when it reflects a long-standing legislative and judicial practice of administering a particular sanction through the civil justice system. In Kansas v Hendricks, ${ }^{85}$ the Court held that potentially indefinite involuntary civil commitment of sexually violent predators did "not establish criminal proceedings" and therefore did not violate the Double Jeopardy or Ex Post Facto Clauses.

While the Court has narrowed the gap between the civil and criminal justice systems through these cases imposing serious sanctions, it continues to assess each proceeding under the Ward test. Thus, the banishment of gang members in a legislatively labeled civil proceeding must still be carefully evaluated to determine whether it is in reality a criminal sanction depriving defendants of procedural safeguards. This Comment argues that, despite the Supreme Court's deference to legislative intent and its reluctance to provide criminal procedural protections to proceedings denominated as civil, the civil banishment of gang members is so extreme that it should be recognized as a criminal punishment.

\section{Application of the Court's Tests to the Cicero Ordinance and Civil Banishment}

Despite its civil label, this Part argues that civil banishment pursuant to measures such as Cicero's gang free zones ordinance is so punitive in purpose and in effect that courts applying the Ward test would ignore the civil legislative label and provide the constitutional protections of criminal proceedings to defendants.

In determining the constitutionality of civil banishment, the Ward test applies. ${ }^{87}$ The result of part one of the test will be clear; in passing the ordinance, the legislature will demonstrate its intent to create a civil proceeding. For example, the Cicero ordinance unambiguously states the legislature's preference under part one of the Ward test. The

84522 US at 103-05 (holding that Double Jeopardy Clause was not violated by subsequent criminal prosecution, even though the prior civil proceedings deprived the defendants of their livelihood, because Congress intended the monetary penalties and debarment sanctions to be civil in nature and there was not the "clearest proof" required to show that the penalties and debarments were in fact criminal).

85521 US 346 (1997).

86 Id at 361-69 (holding that Kansas statute providing for the civil confinement of sexually violent predators did not establish criminal proceedings under the Ward test because the state's intent to create a civil proceeding was clear from the placement of the law in the probate code, rather than in the criminal code, and the defendant had failed to "satisfy [the] heavy burden" of showing that the statute was so punitive as to negate the state's intention).

87 See text accompanying notes $68-70,74-77$. 
preamble to the ordinance states that the town's intent was "to create a civil remedy against street gangs and their members" because their activities "present [ ] a clear and present danger to public order and safety." Having attempted to create a civil penalty under the first part of the Ward test, the analysis proceeds to the second part."

Under this part of the Ward test, the legislature's intent will only be negated where there is the "clearest proof" that the "statutory scheme [is] so punitive either in purpose or effect as to negate [legislative] intention." Under a straightforward application of this part, civil banishment is punitive enough to negate the legislative label. Banishing someone from a town is far more serious than typical civil penalties." Furthermore, as will be discussed in Part III, banishing gang members under the ordinance would likely be found to be excessive under current banishment law and is unlikely actually to achieve the goal of reducing overall gang-related activity. Banishing gang members also seems excessively punitive in light of available alternatives, such as criminally prosecuting the underlying behavior or seeking civil public nuisance injunctions against the gang members' behavior itself without banishing individuals from their homes. Therefore, given the excessive nature of banishment, a court would likely find that the clear proof needed to negate the civil label is present and criminal procedural protections should be provided despite the legislative intent to create a civil proceeding.

As an alternative to this facial application of the second part of the Ward test, the Mendoza-Martinez factors ${ }^{92}$ provide a list of considerations to use in making this determination. ${ }^{93}$ First, banishment involves "an affirmative disability or restraint" "even though it does not involve the paradigmatic criminal punishments of imprisonment or detention." For example, under the Cicero ordinance, accused gang members whom the hearing officer finds to have engaged in gangrelated criminal activity are "ordered to vacate [their] residence[s]" in Cicero, and are fined $\$ 500$ a day if they are found within the town

8 Gang Free Zones Ordinance, Preamble (emphasis added).

89 Ward, 448 US at 248-49 (stating that the first part of test to determine if a proceeding is criminal or civil involves determining the legislative intent and that if the intent is to create a civil penalty, then the second part of the test must be considered).

90 Id.

91 See Mann, 101 Yale L J at 1809 (cited in note 56) (discussing the paradigmatic criminal and civil remedies).

92 See text accompanying notes 78-79.

93 See text accompanying notes 74-77.

94 Mendoza-Martinez, 372 US at 168.

95 See Mann, 101 Yale L J at 1809-10 (cited in note 56) (discussing the paradigmatic criminal and civil remedies).

96 Gang Free Zones Ordinance $\$ 25-300(a)(G)$. 
thereafter. ${ }^{97}$ One could argue that this is not a physical restraint on gang members because they are free to live in any other community they choose. However, while the banishment may not be a typical physical restraint, it does impose a disability on gang members by restraining them from living in Cicero. Furthermore, this may not be an affirmative disability or restraint because a gang member, in theory, could pay the fine and stay within Cicero. However, the high daily fine for remaining in the town effectively expels gang members because they are unlikely to be willing to incur the high cost associated with remaining there. Therefore, civil banishment is effectively removing individuals from the entire community just as imprisonment would. This is a greater affirmative disability or restraint than a large onetime fine or civil forfeiture.

Second, banishment has "historically been regarded as punishment." Justice Brewer stated that "banishment of a citizen is punishment, and punishment of the severest kind." Black's Law Dictionary defines banishment as a "punishment inflicted upon criminals, by compelling them to leave a country for a specified period of time, or for life." Typically, banishment is imposed as a condition of probation or parole,${ }^{101}$ further indicating that it is historically associated with punishment.

The third factor to consider is whether sanctions pursuant to the ordinance "come[ ] into play only on a finding of scienter." ${ }^{112}$ The Cicero ordinance does not directly contain any mens rea or subjective mental element requirement before an accused gang member may be banished from the town. However, the ordinance does require that the hearing officer find that the accused "has engaged in gang-related criminal activity" before ordering him to leave Cicero. ${ }^{100}$ Although the analysis under this factor may initially seem unclear, it ultimately points to negating legislative intent to create a civil penalty because the gang-related criminal activity necessary for banishment would require scienter. The scienter requirement would exist in any civil ban-

97 Id $\S 25-300$ (c)(A)-(B).

98 Mendoza-Martinez, 372 US at 168.

99 United States v Ju Toy, 198 US 253, 269 (1905) (Brewer dissenting) (condemning Court's denial of writ of habeas corpus to individual forbidden from reentering United States). See also Jonathan Elliot, ed, 3 The Debates in the Several State Conventions on the Adoption of the Federal Constitution 555 (Taylor \& Maury 2d ed 1854) (" $[$ I]f a banishment [from a country] be not a punishment, ... it will be difficult to imagine a doom to which the name can be applied.").

100 Black's Law Dictionary 97 (West 6th ed 1991) (emphasis added).

101 See Wm. Garth Snider, Banishment: The History of Its Use and a Proposal for Its Abolition under the First Amendment, 24 New Eng J on Crim and Civ Confinement 455, 456 (1998) (noting that banishment is "often a condition of probation or parole" and discussing implications for how banishment is applied).

102 Mendoza-Martinez, 372 US at 168.

103 Gang Free Zones Ordinance $\$ 25-300(a)(G)$. 
ishment ordinance that was premised on prior criminal behavior as the condition to initiate banishment proceedings.

The next factor to consider is whether the sanction will "promote the traditional aims of punishment-retribution and deterrence."104 The Cicero ordinance seeks to promote the traditional aims of criminal law rather than the traditionally compensatory aims of civil law. ${ }^{\text {tos }}$ The ordinance seeks to deter gang-related activity that is viewed as a danger to the public safety. ${ }^{106}$ The ordinance is aimed at reducing risks caused by gang members' activity and seeks retribution for past gangrelated criminal activity. It is not focused on compensation for actual injuries because the moving party, the town, ${ }^{107}$ does not seek any damages under the ordinance.

The fifth Mendoza-Martinez factor focuses on whether the ordinance applies to behavior that is "already a crime." somewhat difficult to apply literally because civil banishment does not usually penalize specific behavior. For example, the Cicero ordinance allows the town to banish gang members if they are found to have engaged in any gang-related criminal activity that "presents a clear and present danger to the public order and safety." argues for placing the ordinance on the criminal, rather than civil, side of the criminal-civil distinction because the ordinance can only apply if the accused has been involved in a dangerous activity that could be punished criminally.

The sixth factor to consider is whether an alternative purpose for civil banishment may be assigned. ${ }^{110}$ Banishment may serve a broad deterrent purpose in addition to stopping an individual's conduct. For example, in addition to its primary purpose of ridding Cicero of existing gang members, the Cicero ordinance seeks to deter others from becoming gang members or committing gang-related criminal offenses. This deterrent purpose is a traditional goal of criminal law. However, an alternative deterrent purpose of the ordinance is insufficient to negate the legislative intent and turn the civil sanction into a

104 Mendoza-Martinez, 372 US at 168 . This continues to be a factor; however, the presence of a deterrent aim alone will be "insufficient to render a sanction criminal, as deterrence may serve civil as well as criminal goals." Hudson, 522 US at 105 (internal quotations omitted).

105 See notes 62 and 66 and accompanying text.

106 Gang Free Zones Ordinance, Preamble.

107 Id \& 25-300(a)(A), (C) (stating that the Superintendent of Police shall file a hearing request under the ordinance and the Town Attorney shall draft the complaint). Having a government entity as the moving party is a traditional characteristic of the criminal rather than civil law. See Mann, 101 Yale L J at 1812 (cited in note 56) (discussing the difference in the moving party in criminal and civil proceedings and noting that the government is typically the moving party in . a criminal proceeding while private parties typically control a civil one).

108 Mendoza-Martinez, 372 US at 168.

109 Gang Free Zones Ordinance $\$ 25-300(a)(G)$.

110 Mendoza-Martinez, 372 US at 168-69. 
criminal one." Therefore, the results under this factor standing alone do not argue in favor of declaring the Cicero ordinance to be criminal in nature.

The final Mendoza-Martinez factor asks whether the ordinance "appears excessive in relation to the alternative purpose assigned." Gang-related crime and violence is a major problem that has resisted traditional law enforcement techniques, ${ }^{113}$ and the goals of deterring others from becoming gang members or committing gang-related crimes and protecting the community are clearly admirable and desirable. However, banishing people from a town seems to be an extreme measure to accomplish these purposes. As will be discussed in Part III, banishing gang members from a town would likely be found to be excessive under current state banishment law and is unlikely to actually achieve the goal of reducing overall gang-related activity. So banishing someone from an entire town, even a gang member, also argues in favor of denominating the punishment as criminal because it is excessive in relation to the alternative deterrent purposes of the ordinance. Therefore, the results of the analysis under all but one of the seven Mendoza-Martinez factors argue in favor of the position that Cicero is imposing a criminal punishment through a civil hearing.

Advocates of civil banishment might point to recent Supreme Court decisions allowing the imposition of serious sanctions through the civil system, but reliance on these precedents would be misguided. As noted in Part II.B, the Court has allowed the legislature to establish civil forfeiture proceedings that complement criminal penalties, but the Court has been reluctant to expand these civil sanctions beyond taking property. Civil banishment goes beyond the simple levying of a fine or the taking of property; it deprives the defendant of freedom in the same way revoking a person's citizenship or imprisoning her deprives her of freedom.

An advocate of civil banishment might point to Hendricks as the strongest case for upholding civil banishment. In Hendricks, the Court held that potentially indefinite involuntary civil commitment of sexually violent predators was constitutionally permissible. ${ }^{14}$ Hendricks is inapposite. First, the Kansas statute at issue in Hendricks provides for civil commitment only of a person who "suffers from a mental abnormality or personality disorder which makes the person likely to en-

111 See Hudson, 522 US at 105 (stating that the "mere presence" of a deterrent purpose "is insufficient to render a sanction criminal, as deterrence may serve civil as well as criminal goals") (internal quatations omitted).

112 Mendoza-Martinez, 372 US at 169.

113 See Part I.A.

114 Hendricks, 521 US at 361-69. 
gage in the predatory acts of sexual violence."115 The civil system has traditionally been used to commit the mentally ill since colonial times. ${ }^{116}$ The legislature in Hendricks did not attempt to implement a civil statute that inflicted a punishment that is disfavored in the civil justice system. By contrast, as discussed in Part III below, banishment has long been disfavored, even in the criminal context, and it has never been used extensively like the commitment of the mentally ill.

In Hendricks, the Court stressed that Kansas had "disavowed any punitive intent" ${ }^{\prime \prime 1}$ in the law allowing for the civil commitment of sexually violent predators and that the law did "not implicate either of the two primary objectives of criminal punishment: retribution or deterrence."118 The Court found that Kansas was "not seeking retribution for a past misdeed" because it used past criminal conduct solely as evidence of "mental abnormality" or evidence that the person would likely be dangerous in the future."

On the other hand, civil banishment does implicate the traditional goals of criminal punishment. For example, the Cicero ordinance requires that the hearing officer find that the accused has "engaged in gang-related criminal activity" ${ }^{\prime 22}$ and does not specify that the past conduct is to be used only as evidence of potential future dangerousness. It seems instead that 'Cicero is seeking retribution for past criminal gang activity.

The Court in Hendricks also found that Kansas did not intend the civil commitment to serve the traditional deterrent purpose of criminal punishment because the people Kansas sought to confine were "by definition" incapable of "exercising adequate control over their behavior." ${ }^{\prime 21}$ The threat of confinement is therefore unable to deter such persons. ${ }^{122}$ In contrast, the Cicero ordinance serves the traditional criminal law objective of deterring gang-related activity by providing probation if the accused agrees to cease participation in illegal gang activity and threatening banishment if he does not. ${ }^{123}$ There is no indication that the gang members are not capable of being deterred.

115 Id at 357 (discussing the Kansas civil commitment statute).

116 Id at 357 (noting that the Court has "consistently upheld" civil commitment of "people who are unable to control their behavior and who thereby pose a danger to the public health and safety" and listing sources that trace the history of civil commitment in the eighteenth and nineteenth centuries and colonial America).

117 Id at 368.

118 Id at 361-62.

119 Id at 362.

120 Gang Free Zones Ordinance $\$ 25-300(a)(G)$.

121 Hendricks, 521 US at 362.

122 Id at 363.

123 Gang Free Zones Ordinance $\$ 25-300(a)(H)$. 
The Hendricks Court also indicated that the state did not intend for commitment to last any longer than necessary and did not intend for the commitment to be punitive. ${ }^{124}$ The Court stressed that civil confinement under the Kansas law was only potentially, and not definitely, of unlimited duration, with a provision for immediate release upon a showing that the confined person is "safe to be at large."125 In contrast, civil banishment would be for unlimited duration unless a city established a system to readmit gang members who demonstrate that they are no longer engaged in gang activity. For example, the Cicero ordinance indefinitely banishes gang members who do not opt for the oneyear probation period and has no provision for readmitting them to the city if they later renounce gang activity. ${ }^{125}$

Finally, Kansas provided "numerous procedural and evidentiary protections" to confine the civil commitments to "only a narrow class of particularly dangerous individuals." ${ }^{\prime 27}$ While one could argue that the provision of heightened procedural protections makes the Kansas statute more criminal in nature than the Cicero ordinance, the Court saw these protections as demonstrating the care that Kansas was taking to narrow the scope of civil commitment under the act. ${ }^{128}$ In contrast, the Cicero ordinance specifically provides low evidentiary standards $^{12}$ and indicates the town's intent to cast a broad net and remove as many gang members as possible. Other civil banishment ordinances would have to share this feature of the Cicero ordinance to have a sufficient impact given the large number of gang members in many communities. Furthermore, one could argue that with Kansas already providing "strict procedural safeguards,", be as concerned that Kansas was depriving people of constitutional criminal procedural protections.

Taken together, these differences indicate that there is more "clear proof" that the Cicero ordinance establishes criminal proceedings, despite its civil label, than the Court had before it in Hendricks.

124 Hendricks, 521 US at 364 (noting that if the state seeks to detain someone under the statute for more than one year, a court must find beyond a reasonable doubt that the "same standards as required for the initial confinement" are met).

125 Id at 364.

126 The ordinance does provide for a one-year probationary period if the accused renounces gang activity, Gang Free Zones Ordinance $\$ 25-300(\mathrm{a})(\mathrm{H})$, but there is no provision for ending the banishment once a gang member is ordered to leave the city.

127 Hendricks, 521 US at 364-65 (noting that Kansas's choice to afford "procedural protections does not transform a civil commitment proceeding into a criminal prosecution").

128 Id at 364 (stating that the "numerous procedural and evidentiary protections afforded [by Kansas] demonstrate that the Kansas legislature has taken great care to confine only a narrow class of particularly dangerous individuals, and then only after meeting the strictest procedural standards").

129 Gang Free Zones Ordinance $\$ 25-300(a)(E)-(F)$.

130 Hendricks, 521 US at 368. 
Therefore, the Court would be unlikely to let the civil denomination of banishment stand even though it let civil confinement survive in Hendricks.

Despite the Supreme Court's usual deference to legislative preference, civil banishment is "so punitive [ ] in purpose [and] effect" that courts should negate the civil label and classify the proceeding as criminal. Furthermore, the Cicero Gang Free Zones Ordinance is distinguishable from recent Supreme Court cases, even Hendricks, that have allowed serious punishments through civil hearings. ${ }^{132}$

\section{BANISHING GANG MEMBERS UNDER EXISTING BANISHMENT LAW}

Even if the enactors of an ordinance banishing gang members properly classify the proceedings as criminal and provide the constitutionally required procedural protections, banishment imposed on gang members is unlikely to be upheld by courts. This Part discusses the current state of banishment law with a focus on intrastate, rather than interstate, banishment because the Cicero method (banishment from a single community), is effecting an intrastate banishment. This Part examines the general reluctance of courts to uphold banishment conditions. This Part then argues that banishing gang members should not be allowed by courts under the existing law because it is not narrowly tailored, it is unnecessarily severe and restrictive, and it merely pushes gang members into other areas, creating dissension between neighboring communities.

\section{A. Current Banishment Law}

1. Interstate banishment.

Historically, banishment was a severe form of criminal punishment used to rid communities of undesirable individuals. ${ }^{133}$ Banishment reflects a community's view that it does not want to take the time to rehabilitate an offender, or that it sees an offender as incapable of rehabilitation and that the community feels that its safety is best served by expelling the offender from the community. ${ }^{134}$ At the federal level, "[t]here is no banishment prohibition in the United States Con-

131 Ward, 448 US at $248-49$.

132 Hendricks, 521 US at 369 (allowing potentially indefinite civil confinement for sexually violent predators).

133 See text accompanying notes 98-101. See also Snider, 24 New Eng J on Crim and Civ Confinement at 459-65 (cited in note 101) (discussing historical uses of banishment dating back to the Codes of Hammurabi and the Old Testament).

134 See Snider, 24 New Eng J on Crim and Civ Confinement at 456 (cited in note 101) (discussing the penological bases for banishment). 
stitution," ${ }^{135}$ and banishment was not cruel and unusual punishment at common law. ${ }^{135}$ However, the majority of federal and state courts that have addressed interstate banishment have held it to be illegal, ${ }^{137}$ and at least fifteen state constitutions explicitly prohibit banishing people from the state. ${ }^{1.8}$ The majority of courts that have rejected interstate banishment have found that it is not related to the rehabilitative and deterrent goals of the criminal justice system and that it raises serious interstate comity problems when one state "make[s] other states a dumping ground for [its] criminals." ${ }^{139}$

\section{Intrastate banishment.}

Despite the fairly uniform rejection of interstate banishment, states do not agree on whether intrastate banishment may be imposed as a criminal sentence or a condition of probation or parole. $.^{140} \mathrm{Ban}-$ ishment cases are "uncommon," and the majority of states have not addressed the intrastate banishment issue. ${ }^{162}$ However, some states have indicated a willingness to uphold intrastate banishment conditions in limited circumstances ${ }^{143}$ while others prohibit intrastate as well

135 Ray v McCoy, $174 \mathrm{~W}$ Va 1, 321 SE2d 90, 95 (1984) (Miller concurring).

136 People v Baum, 251 Mich 187, 231 NW 95, 96 (1930) (discussing the fact that banishment to criminal colonies was common in England).

137 Snider, 24 New Eng J on Crim and Civ Confinement at 466 (cited in note 101) (noting that most state and federal courts addressing legality of interstate banishment have declared it illegal and discussing their reasons for doing so).

138 Id at 465 (discussing state prohibitions on banishing or exiling individuals from the state).

139 Commonwealth $v$ Pike, 428 Mass 393, 701 NE2d 951, 960-61 (1998) (invalidating a condition of probation prohibiting a party from entering Massachusetts during the period of his probation). See also Baum, $231 \mathrm{NW}$ at 96 (stating that "permit[ting] one state to dump its convict criminals into another ... would tend to incite dissension, provoke retaliation, and disturb that fundamental equality of political rights among the several states which is the basis of the Union itself").

140 See Snider, 24 New Eng J on Crim and Civ Confinement at 470 (cited in note 101) (stating that most courts hold that any banishment sentence is illegal but that some courts have upheld intrastate banishment conditions).

141 People v Harris, 238 Ill App 3d 575, 606 NE2d 392, 396 (1992) (noting that "banishment cases are for the most part, uncommon").

142 A survey of state case law revealed that the following states have not addressed intrastate banishment conditions: Arkansas, Arizona, Colorado, Connecticut, Delaware, Florida, Hawaii, Idaho, Indiana, Kansas, Kentucky, Louisiana, Maine, Massachusetts, Maryland, Michigan, Missouri, Montana, Nebraska, Nevada, New Hampshire, New Mexico, New York, North Dakota, Ohio, Oklahoma, Pennsylvania, Rhode Island, South Carolina, South Dakota, Tennessee, Utah, Vermont, Washington, West Virginia, Wisconsin, and Wyoming. The District of Columbia has also not addressed intrastate banishment conditions.

143 A survey of state case law reveals that Alabama, Alaska, California, Georgia, Illinois, Minnesota, Mississippi, Oregon, and Texas have considered intrastate banishment conditions and upheld them in limited circumstances, or indicated a willingness to do so. See Beavers $v$ State, 666 S2d 868, 871 (Ala Crim App 1995) (holding that banishment from a county pursuant to a parole condition was allowed because it was voluntarily accepted); Peratrovich v State, 903 P2d 1071, 1079 (Alaska Ct App 1995) (holding that before imposing condition banishing defendant from 
as interstate banishment. ${ }^{144}$ When determining the validity of a ban-

his home, the judge must have good reasons for rejecting lesser restrictions); Jones $v$ State, 727 P2d 6,7-8 (Alaska Ct App 1986) (holding that an area restriction must be connected to underlying offense, must not be overly severe, and must be related to rehabilitation of the offender); People v Watkins, 193 Cal App 3d 1686, 1689 (1987) (upholding very narrow banishment condition because it was related to the defendant's crimes and preventing future criminality); People $v$ Beach, 147 Cal App 3d 612, 620-23 (1983) (striking banishment condition that was not necessarily rehabilitative and "was unreasonably broad in light of the desired goal"); In re White, $97 \mathrm{CaI}$ App 3d 141,147-52 (1979) (modifying and limiting banishment condition because there was "little factual nexus" between condition and future criminality except in small area defendant was banished from and the condition was unduly harsh); State $v$ Collett, $232 \mathrm{Ga} 668,208$ SE2d 472, 474 (1974) (upholding condition banishing the defendant from seven counties in Georgia for one year, as there was no showing that the one-year period was unreasonable and no showing that banishment was unrelated to the defendant's crime); United States v Cothran, 855 F2d 749, 75253 (11th $\mathrm{Cir} 1988$ ) (upholding banishment condition requiring defendant to stay out of Georgia county because defendant could enter the county with permission); Adams $v$ State, $2000 \mathrm{Ga}$ App LEXIS 35, 2 (holding that banishing defendant from several Georgia counties for thirty years was not unreasonable); Sanchez $v$ State, 234 Ga App 809, 508 SE2d 185, 186 (1998) (invalidating sentence banishing defendant from state and noting that banishment from areas within Georgia must be logically related to rehabilitation of the defendant); Wyche v State, $197 \mathrm{Ga}$ App 148, 397 SE2d 738, 739 (1990) (banishment from five county area of Georgia, for four-year period, not unreasonable); Kerr v State, 193 Ga App 165, 387 SE2d 355, 359 (1989) (banishment permissible if it is for a reasonable duration and bears logical relationship to the rehabilitative purpose of the punishment); Parrish v State, 182 Ga App 247, 355 SE2d 682, 683-84 (1987) (defendant must show that banishment is unreasonable or unrelated to rehabilitative purpose of sentence in order to have banishment set aside); Edwards $v$ State, 173 Ga App 589, 327 SE2d 559, 561 (1985) (banishment of convicted criminal from a county is a permissible condition of probation); Wilson $v$ State, $151 \mathrm{Ga}$ App 501, 260 SE2d 527, 530-31 (1979) (banishment not per se violative of public policy and is within broad discretion of trial judge); In re J.G., 295 Ill App 3d 840, 692 NE2d 1226, 1229 (1998) (holding that geographical restrictions as condition of juvenile probation must be reasonably related to the underlying crime and rehabilitation, and that in the instant case banishment had nothing to do with the "delinquent acts or rehabilitation"); People v Pickens, 186 III App 3d 456, 542 NE2d 1253, 1257 (1989) (holding that probation condition imposing geographic restriction from fifty block area was allowable because the probationer could obtain permission to reenter the area for legitimate reasons and this "remove[d] the taint of banishment from the restriction"); State v Holiday, 585 NW2d 68,70-71 (Minn Ct App 1998) (finding ordinance could not allow for banishment of trespasser from all public housing because of overbreadth concerns); $C o b b$ v State, 437 S2d 1218, 1221 (Miss 1983) (upholding probation condition requiring probationer to remain 125 miles outside of the county in which he committed his crime); Martin $v$ Board of Parole and Post-prison Supervision, 327 Or 147, 957 P2d 1210, 1212, 1216-17 (1998) (upholding condition barring defendant convicted of sexually abusing a child from entering most of the victim's county); Owens v Board of Parole, 113 Or App 507, 834 P2d 547, 549 (1992) (holding that condition barring sex offender from entire county of victim was overbroad but indicating that more narrow restrictions would be allowed); State v Ferre, 84 Or App 459, 734 P2d 888, 889-90 (1987) (same); State v Jacobs, 71 Or App 560, 692 P2d 1387, 1389 (1984) (invalidating condition banishing probationer from entire town and holding that condition must be more "narrowly drawn" to fit specific crime); Johnson v State, 672 SW2d 621, 623 (Tex Ct App 1984) (holding that banishing defendant from county was not reasonably related to rehabilitation and was unduly restrictive of defendant's liberty).

144 A survey of state case law reveals that Iowa and North Carolina have considered intrastate banishment conditions and have essentially prohibited them. See Burnstein v Jennings, 231 Iowa $1280,4 \mathrm{NW} 2 \mathrm{~d} 428,429$ (1942) (holding that trial court had no right to order defendant to stay out of county); State v Churchill, 62 NC App 81, 302 SE2d 290, 292-93 (1983) (noting that a North Carolina court has no power to issue a banishment sentence and that North Carolina defines banishment broadly to include banishment from "a city, place, or country, for a specific pe- 
ishment order, courts typically look to at least three general factors. First, the banishment must be "related logically to the rehabilitative purposes of the sentence." ${ }^{145}$ Second, the prohibited area in the banishment condition must be tailored in some way to fit the underlying crime. ${ }^{145}$ Finally, the banishment condition cannot be "unnecessarily severe and restrictive."

Under these guidelines, the determination of the legitimacy of a banishment condition is highly fact specific. ${ }^{143}$ In cases of egregious misconduct, such as sexual abuse of a child, courts tend to permit more sweeping banishment conditions to protect past victims. ${ }^{199}$ Generally, courts seem to prefer banishment conditions barring individuals from crime-ridden areas or locations frequented by past victims to those prohibiting individuals from entering entire communities. ${ }^{150}$

riod of time, or for life"); State $v$ Setzer, 35 NC App 734, 242 SE2d 509, 511 (1978) (noting that there is a well settled prohibition on banishment in North Carolina, but finding that restriction from area in and around courthouse was not illegal banishment); State v Culp, 30 NC App 398, 226 SE2d 841, 842 (1976) (holding that condition requiring defendant to move his trailer home constituted impermissible banishment from situs of trailer).

145 Sanchez, 508 SE2d at 186 (stating that banishment must be related to rehabilitative purposes of a probation sentence). See also Commonwealth v Pike, 428 Mass 393, 701 NE2d 951, 959-60 (listing cases in which conditions banishing probationers from small geographic areas were upheld because they "served the goals of probation" and noting that "banishment from a large geographical area ... struggles to serve any rehabilitative purpose") (internal citations omitted).

146 See Jones, $727 \mathrm{P} 2 \mathrm{~d}$ at 8 (reversing condition of probation prohibiting the defendant from being within a forty-five block area in part because there was no "clear nexus between the area and [defendant's] misconduct"); Martin, 957 P2d at 1217 (upholding condition barring defendant convicted of sexually abusing a child from entering most of the victim's county); Jacabs, 692 P2d at 1389 (invalidating condition banishing probationer from an entire town because the condition should have been "more narrowly drawn" to the offense).

147 Jones, $727 \mathrm{P} 2 \mathrm{~d}$ at 8 (reversing condition of probation prohibiting the defendant from being within a forty-five block area in part because it was unreasonably restrictive). See also Holiday, 585 NW2d at 70 (construing a Minneapolis ordinance as banishing a trespasser from only a few properties and not all public housing to avoid overbreadth concerns); Owens, 834 P2d at 549 (invalidating parole condition barring a sex offender from an entire county because the restriction was unnecessarily broad to accomplish the goal of protecting the victim); Ferre, $734 \mathrm{P} 2 \mathrm{~d}$ at 889-90 (reversing an order barring probationer from an entire county because it was broader than necessary to protect the victims).

148 See Snider, 24 New Eng J on Crim and Civ Confinement at 472-73 (cited in note 101) (noting that the "illegality of banishment turns upon the circumstances under which the condition is imposed").

149 See $C o b b, 437$ S2d at 1221 (upholding five-year probation condition requiring probationer to remain 125 miles outside of the county in which he shot his nephew); Martin, 957 P2d at 1216-17 (upholding condition barring defendant convicted of sexually abusing a child from entering most of the victim's county).

150 See, for example, Holiday, 585 NW2d at 71 (invalidating an order banishing an individual from all public housing projects when he had only trespassed in one); Jacobs, 692 P2d at 1389 (banishment condition barring probationer from entire town should have been "more narrowly drawn" to the offense and to protecting past victims). 


\section{B. Banishment of Gang Members}

Civil banishment effectively imposes an intrastate banishment of gang members by ordering them to leave a town. This Part argues that a court is unlikely to uphold such a condition under existing banishment law.

First, banishment of gang members does not serve any rehabilitative purpose. One could argue that removing gang members from a town is likely to sever their ties to their gang and reduce the likelihood that they will engage in further gang-related conduct. ${ }^{\text {ist }}$ Civil banishment, however, simply orders gang members to leave town and does not rehabilitate them in any way or try to reduce their future criminal behavior in other communities. On the other hand, this factor is not dispositive because the cases requiring a rehabilitative purpose have been in the probation context, ${ }^{152}$ where rehabilitation is clearly the goal. Supporters could argue that the goal of civil banishment measures, such as the Cicero ordinance, is not gang member rehabilitation but rather community protection and that banishing gang members is therefore serving the underlying goals of the measures. ${ }^{155}$

Second, banishment of gang members such as that effected by the Cicero ordinance is not narrowly tailored geographically to match gang members' offenses as required in most intrastate banishment cases. ${ }^{1 \text { As }}$ A gang free zones ordinance simply banishes gang members from the entire town, not only from specific areas where they engaged in criminal behavior. A court is unlikely to uphold such a broad geographic restriction that is unrelated to specific offenses. For example, there is no indication that the underlying criminal activity, required for banishment under the Cicero ordinance, ${ }^{135}$ must be similar to the egre-

151 See Michael George Smith, Note, The Propriety and Usefulness of Geographical Restrictions Imposed as Conditions of Probation, 47 Baylor L Rev 571, 586-87 (1995) (noting that banishing individuals from an area to get them out of the way serves no rehabilitative purpose but that it "could break a chain of social contacts that has proven to cause criminal behavior in the past"). Smith's argument that removing people from their established community may break social contacts that have facilitated criminal behavior may be particularly persuasive in the gang context due to the potential problems gang members might face if there are only rival gangs in the town in which they relocate. Consider Jeffrey Fagan, Gangs, Drugs, and Neighborhood Change, in Huff, ed, Gangs in America 39, 41 (cited in note 14) (discussing that gangs have certain "turfs" and that fights are common among gangs). However, given the large number of gangs, it is likely that many gang members will in fact be able to find a new gang to associate with in the community that they move to and will continue to commit gang-related crime. Consider James F. Short, Jr., Foreword: Diversity and Change in U.S. Gangs, in Huff, ed, Gangs in America vii, xi (stating that "most gangs are neither very stable in membership [n]or very cohesive").

152 See note 145 and accompanying text.

153 See Slater, Suburb Gives Gang Members 60 Days to Leave, Austin American-Statesman at A12 (cited in note 33) (quoting Cicero town president as stating that her "concern is protecting the residents of the town of Cicero").

154 See text accompanying note 146.

155 Gang Free Zones Ordinance $\$ 25-300(a)$ (G). 
gious crimes such as child sexual abuse and murder that have led courts to uphold such broad geographic banishment conditions. ${ }^{166}$ For this reason, a court is unlikely to uphold a broad banishment condition even to stop the serious threat of gang activity. ${ }^{157}$

Finally, a court is likely to find that banishment of gang members is unnecessarily severe and restrictive. For example, overlapping with the previous factor, the fact that banishment under the Cicero ordinance is from the entire town makes the condition overly restrictive. Furthermore, most banishment conditions allowed by courts are limited in duration, ${ }^{158}$ while banishment under the Cicero ordinance is permanent. The ordinance contains no provision specifying a period of time for the banishment and no provision for an excluded gang member to seek readmission to the town. A final indication that the banishment condition is overly restrictive is that it does not allow the banished gang member to enter the town for any reason. ${ }^{159}$

In addition to these factors generally considered in determining the legality of intrastate banishment conditions, the banishment of gang members is unlikely to be upheld because it merely pushes gang

156 See text accompanying note 149.

157 The broad nature of the civil banishment of gang members from an entire town is one feature that distinguishes it from the more narrowly tailored nuisance abatement injunctions that have withstood a constitutional challenge in California. See notes 22,30 , and accompanying text. For example, unlike the broad provisions in the Cicero ordinance, nuisance abatement injunctions are focused on more specific behavior and on more targeted problem areas of the community. See notes 22-25 and accompanying text; Werdegar, Note, 51 Stan L Rev at 416 (cited in note 10) (noting that a city will identify and focus on a neighborhood "with an unusually high crime rate that is known to be the turf of a particular urban street gang"). The more narrow focus of nuisance abatement injunctions threatens the liberty interest of gang members less than a broad banishment from an entire town, so a court is more likely to uphold an injunction against a gang than a broad banishment condition exiling them from the entire town. Furthermore, courts have traditionally issued nuisance abatement injunctions, see Werdegar, Note, 51 Stan L Rev at 414 (stating that public nuisance doctrine is "centuries-old"), while they have traditionally been reluctant to allow banishment, see notes $137-40$ and accompanying text. This also makes the nuisance injunctions easier to defend because a court seems more likely to use the established public nuisance doctrine in innovative ways to combat gangs than it is to increase the use of the generally disfavored banishment remedy.

158 Compare Bagley v Harvey, 718 F2d 921, 925 (9th Cir 1983) (holding that parole condition banishing defendant from the state of Washington was not cruel and unusual punishment because the banishment was not permanent-defendant could return at the end of his parole term), with Dear Wing Jung $v$ United States, 312 F2d 73, 76 (9th Cir 1962) (holding that condition requiring alien to leave the United States was the equivalent of permanent banishment from the United States and as such was "either a 'cruel and unusual' punishment or a denial of due process of law").

159 This factor would likely be particularly persuasive in an Illinois court because Illinois has held that allowing a probationer to enter a prohibited area for a legitimate reason "removes the taint of banishment" from a condition. People v Pickens, 186 Ill App 3d 456, 542 NE2d 1253, 1257 (1989) (holding that a court may impose a condition barring a defendant from certain areas if the banishment is reasonably related to the offense "provided that, if the defendant has a legitimate and compelling reason to go to that area or place, he may apply to a specified authority for specific permission" to do so). 
members into other regions, creating dissension between neighboring communities. Typically, comity concerns are discussed in interstate banishment cases. ${ }^{160}$ However, the same principles apply to intrastate banishment. When a town tries to "dump" gang members into surrounding cities, serious problems between communities may arise if gang members join new gangs and continue to commit gang-related crimes in their new community. ${ }^{161}$

Finally, banishment is unlikely to be upheld because of the likelihood of enforcement along racial lines. In a comprehensive commentary on banishment, one commentator argues that banishment should be per se unconstitutional and recognizes as specific problems that banishment may be used as a "vehicle of racial discrimination in certain cases" and as a "means of effecting the political makeup of a [community]" by banishing minority citizens disproportionately and redistributing votes. ${ }^{162}$ For example, critics of the Cicero ordinance have argued that it will work along racial lines. ${ }^{163}$ While all criminal law enforcement is open to attack as discriminatory, banishing citizens deprives them of the right to vote in future elections to change current community policies and makes discretion particularly dangerous. Furthermore, if a court in fact allowed banishment through the civil, rather than criminal, justice system contrary to the argument in Part II, the lack of procedural safeguards would likely lead to a higher rate of wrongful convictions that would exacerbate the racial bias problem.

In light of these considerations and the factors generally used to determine the legality of intrastate banishment conditions, a court is unlikely to uphold the banishment of gang members.

\section{CONCLUSION}

Gang-related crime in America is staggering and communities are understandably searching for new ways to control gang violence. Communities are turning away from ineffective traditional criminal law techniques and are looking to innovative civil methods to fight gangs. The town of Cicero, Illinois has tried the novel measure of banishing gang members from the town pursuant to a civil administrative hearing.

However, civil banishment imposes a criminal penalty through a civil hearing and deprives gang members of important constitutional

160 See note 139 and accompanying text.

161 See Snider, 24 New Eng J on Crim and Civ Confinement at 456-57 (cited in note 101) (stating that "if one is banished from one community, he is necessarily relegated to another [and] [a]rguably, the community in which the offender now must reside will find him equally as repugnant as the one from which he was banished").

162 Id at 503-06 (discussing banishment as a means of political and racial oppression).

163 See note 53 and accompanying text. 
procedural protections. Despite the Supreme Court's strong preference for deferring to the civil or criminal label affixed to statutes by legislatures and the high burden of proof a challenger must meet to overcome the legislative denomination, the civil banishment of gang members is likely to transcend its civil legislative label.

Furthermore, even if Cicero provided the necessary procedural protections and recognized the criminal nature of the ordinance, courts would be unlikely to enforce the banishment of gang members under existing banishment law. Banishment imposed on gang members is not tailored in any way to a gang member's criminal behavior but is instead an unnecessarily broad geographical restriction from the entire town. Furthermore, banishment pushes gang problems into surrounding communities and is prone to discriminatory enforcement along racial lines.

While cities should pursue innovative ways to combat the serious problems of gang-related crime, communities should not be allowed to deprive gang members of criminal due process protections or to simply shift their problems into surrounding areas by banishing gang members. Cities should pursue stepped-up enforcement of petty crimes committed by gang members or nuisance abatement injunctions that are more narrowly tailored than broad banishment from an entire town to combat gang-related crime. The Cicero ordinance should not be enforced and other communities should not enact similar measures. 


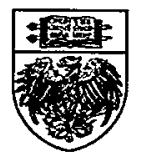

เ 